\title{
Notes on the Fishing Industry of Plymouth.
}

\section{By}

\section{Walter Heape, M.A.g,}

Resident Superintendent of the Plymouth Laboratory of the Marine Biological Association.

In the following Notes on the Fishing Industry of Plymouth the information obtained is divided into three sections, which are again subdivided as follows :

I.-Methods of fishing, localities fished, and fish caught. There are eleven different methods of fishing carried on in Plymouth :

1. Beam trawling. 2. Drift-net fishing. 3. Moored-net fishing. 4. Seine fishing. 5. Bultering, or long-line fishing. 6. Hand-line fishing. 7. Eel spearing. 8. Mullet trapping. 9. Crab and lobster fishing. 10. Shrimp and prawn fishing. 11. Oyster, mussel, and cockle fishing.

II.-Industries connected with the fishing trade carried on in Plymouth :

1. Boat building. 2. Sail making. 3. Rope making. 4. Fish-line making. 5. Net breeding. 6. Fish curing. 7. Fish-skin curing. 8. Fish-oil manufacture. 9. Ice manufacture.

III.-Methods of ownership, wage, apprenticeship, insurance, and sale of fish :

[Nоте,-Mr. Heape's notes are intended to furnish information which will be useful as a preliminary to the investigations to be carried out in the Plymouth Laboratory when it is completed. They are necessarily not the result of original observation, but are compiled from various sources. They have not been published in any shape before the present date, August 8th, 1887.E. R. L.] 
1. Payment of trawlers. 2. Payment of drifters. 3. Payment of hookers. 4. Systems of payment compared. 5. Insurance of trawlers. 6. Insurance of drifters and hookers. 7. Methods of selling and buying fish.

\section{I.-Methods of Fishing. Localities Fished and Fish CaUght.}

\section{Beam Trawling.}

Trawling Smacks.-The boats used for beam trawling in Plymouth average about forty-three tons (43.62); they are cutter or yawl rigged, and are manned by a skipper, two men, and a boy; they are, as a rule, very fast sailers and excellent sea boats.

In confirmation of this latter statement it is most satisfactory to be able to state that, in spite of the heavy weather frequently encountered by the smacks, and the great traffic carried on over a considerable portion of the fishing grounds, during the last seven years there have been but two trawlers lost, one at sea and one in the Sound. Both losses were due to collision. Two lives only have been lost during this time, both these being lives of men drowned in the former of these two accidents.

There are seventy-seven trawlers now sailing from Plymouth, for the most part owned by fishermen, many of whom are skippers of their own boat.

For some years the size of trawlers has been on the increase, the newer vessels being the largest in the port, viz. fifty-five tons. At the present time, however, there is a tendency on the part of the fishermen to prefer smaller boats, about forty tons. Those of them in favour of this change assert-

1. That there is less wear and tear in the smaller than in the larger boats, and the cost of keeping the boat in good order is consequently proportionately less in the smaller than in the larger boats.

2. That the small boats catch, in spite of the smaller sized trawl they are obliged to use, as much fish as the larger boats; the reason of this according to my informants, being, that the smaller sized boats trawl more regularly than the larger boats, increase or decrease of wind during trawling having less effect upon them than upon the vessels of greater tonnage.

In explanation of this, I may state that only sufficient sail is made upon a vessel towing her trawl to enable her to drag it at a certain speed, say from one to three knots an hour. Any sudden and considerable increase of wind driving the boat too rapidly, lifts the trawl off the bottom, so that the fish escape underneath, while a falling off of wind on the other hand, stops the boat altogether, or causes it to trawl too slowly and to make the trawl dig too much into the grouna and pick up too much sand or weed. These variations of the wind act more readily upon the larger than upon the smaller vessels, hence the latter are considered to trawl more regularly than the former, and to catch quite as much fish.

3. That the crew of three men and a boy, while ample for the smaller boat, is scarcely sufficient for the large boat, and yet the difference is not sufficient to oblige the latter to ship an extra hand. The smaller boats are, therefore, more readily handled.

4. That the smaller boats cost less than the larger in the builder's yard.

The obvious advantages of a larger boat are :

1. Increased speed in getting out to the fishing ground and home with fish; and, therefore, increased time for fishing and command of the early market to some extent.

2. The power of using a larger-sized trawl, covering more ground than the trawl of a smaller vessel; and

3. Greater storage capacity.

If trawling here was conducted, as in the North Sea, on the "fleeting system ;" if the trawlers travelled further to sea and remained longer from home, the larger vessels would be a necessity. A North Sea trawler may be as much as eighty tons or even more. 
System of Fishing.-The fleet system of fishing is not in use in the Channel. That is to say, there are no "carriers," steam, or sailing vessels which collect fish from the trawlers on the fishing grounds and bring it to market.

Each smack carries its own fish home. Hence fishing is always carried on comparatively near the shore, and the area fished over by boats landing their fish in Plymouth is necessarily small. This system is called the " single boating system."

Why the fleet system of fishing is not carried on here I do not know, but one of the reasons advanced why it should not be is, that gales in the Channel, especially when from the south-west, are accompanied by very much heavier seas than are usual in the North Sea, and the dangers attending the fleeting system would be greater here than they are even in the North Sea.

The chief danger to be encountered by men fishing on the fleeting system is the exposure in small open boats while carrying the fish from the smacks to the "carrier" which is to take it to market. This work has to be done in all weathers, and is probably the most dangerous work encountered by fishermen.

Steam Trawlers. - There are no steam trawlers in Plymouth, and a recent attempt to introduce two such vessels here has, I am informed, not met with encouragement.

The fishermen are not favorable to steam trawlers, but do not fear competition from them.

They are of opinion that the expenses attending steam trawling, both the orginal cost of the vessel and the working expenses, are more, in proportion to the catch of fish, than the expenses of sailing smacks. They are also of opinion that a steam trawler, although able to fish in calm weather when the sailing smacks are becalmed, would be unable to fish in the heavy seas frequently encountered in the Channel by their cutters and yawls, whose sails only keep them sufficiently steady for trawling purposes.*

* In Falmouth there are six steam vessels, which are used both as steam trawlers and, when required, as tugs. I have yet to learn the fishing grounds they frequent and the effect of rough weather on their fishing returns.
The Trawl.-The trawl is of the ordinary pattern.

Beam.-Runners.-A wooden " beam," usually made of elm, of 44 to $47 \mathrm{ft}$. long, according: to the size of the boat nsing it, is fixed on two iron " runners"-the "trawlheads" -and by this means raised 2 to $3 \mathrm{ft}$. from the ground.

Net.-A purse-shaped net, open at both ends and about $85 \mathrm{ft}$. long, is attached, the upper edge of its mouth to the beam of the trawl, the lower edge to a rope--the " ground rope "-which is in its turn fastened to the lower portion of the runners. By this means the mouth of the net is kept open. The hinder end of the net, which is much narrower than the mouth, is closed during trawling by a rope, which is tied round it; and when the trawl is hauled up with the fish in it, it is hung suspended over the deck, this rope is cast loose, and the catch falls out on to the deck.

Net breeding. - The trawl nets are made or " bred" by the fishermen themselves while at sea. They are made of hemp twine, and are prepared for work when completed by steeping them in a hot solution of tar. The mesh of the net varies from about 4 " square at the mouth to $1 \frac{1^{\prime \prime}}{}$ at the hinder or " cod" end of the net.*

Wear of Net.-The upper part of the net, or "back," lasts-with good luck, $i$. e. if no anchors or wrecks or rocks are come across-for twelve months. The lower part, or "belly," on the other hand, is usually worn out in four months, and this in spite of the fact that it is guarded by extra netting; the lower part of the "cod end" of the net wears out faster than the other lower portions on account of the collection of material at that end and consequent heavier weight on the ground.

Spans.-Two ropes called the "spans" or "bridles," each about fifteen fathoms long, are attached one to each trawl-head and to these "bridles" is attached the "trawlwarp " by which the net is towed.

understand, however, that they do not bring in a good return for their
original cost. original cost.

"For details of the structure of the trawl net, "pockets," "valves," \&c.,
see No. 1l. VOL. 1, NO. I. 
Size of Trawl.-The trawl is hauled on board Plymouth trawlers generally if not always on the port side, and the beam of the trawl is of such a length that when hauled on board one of the runners is fastened just ahead of the aftermost stay, and the other made fast on a level with the extreme end of the stern of the vessel.

Accordingly, a fifty ton trawler will use a trawl with a $4.6 \mathrm{ft}$. beam, and this is found to be about the size of trawl which such a vessel can tow and work most satisfactorily. A smaller vessel will use a smaller trawl.

'Trawling.-The trawl is towed in the direction of the tide, and owing to the complicated tides of this portion of the Channel, great experience and the closest observation is required.

As an example of the complication of the currents in the neighbourhood, it may be mentioned that the tide flows in the Channel between the mainland and the Eddystone for three hours and half after it has turned at the Eddystone, and for three hours after high water in the Sound (No. 14).

A breeze of wind is required for satisfactory work, in fact, the weight of the trawl when partially full is so great that in a light breeze the smack cannot tow it.

The length of the tow-rope is so adjusted that the trawl should drag as lightly as possible over the ground without "lifting." The shorter the tow-rope the more weight is taken off the ground.

The hardest work in connection with this method of fishing is the hauling up of the trawl. The trawl hawser is, by means of a winch, hauled in over the bows of the boat, which is laid to during the process.

In summer weather, when the fishing ground is covered with sand and "scruff" $*$ and the sea smooth, the labour of hauling up the trawl is very great. The net gathers a great amount of mud, weed, and "scruff" at such times, which is a dead weight to lift, and the operation may take a couple of hours. With a slight sea running, however, the boat pitches, and each time she dips a fathom or so of slack rope can be quickly wound in without trouble.

\footnotetext{
* See page 53 .
}

In favorable weather, hauling in the trawl takes about an hour. As much as three tons of fish is at times brought on board in a single haul, but probably the average weight of fish would be about four to five cwt. Several smacks in Brixham are fitted with a donkey engine to do the work of hauling in the net, and one Plymouth smack is provided with this convenience, but it is not usual in the boats on this part of the coast as it is on board the large trawlers on the east coast.*

Day Trawling.-Most of the trawling grounds are within a few hours' sail of Plymouth. In favorable weather the trawlers generally leave port between 4 and 6 a.m. and return during the following afternoon or night, from 4 to 12 p.m., sailing again the next morning at 4 a.m. This they do from Monday morning until Friday night, if the weather remains suitable for so long. Saturday and Sunday the men spend ashore.

Night Trawling.-The Brixham trawlers (Brixham is the largest trawling port on the Channel coast) on the other hand trawl more during the night than during the daytime. The following reason has been given for this : more "prime" or "first-class" fish is caught at night than during the day, the greater number of "coarse" fish, or so-called "offal" fish, being caught during the daytime. At Brixham there is but a small market for coarse fish, while in Plymouth there is a much more ready sale for that class of fish.

If night work is more productive than day work it is much more dangerous. A vessel with her trawl down is helpless and runs considerable risk of being run down by large steamers and vessels at night. This risk on the Plymouth fishing grounds is probably greater than on the grounds mostly frequented by the Brixham smacks.

Summer Fishing, \&c.-In the summer season, when trawl fish is scarce in the Channel, most of the Brixham boats go

* It appears that the reason why a steam winch is not shipped on board Plymouth smacks generally is, that if it was used, a larger share of the be less of the fishing would be absorbed by the boat-owner and there would would be reque for the fishermen, while at the same time the usual crew would be required to work the vessel. 
to the North Sea to fish, and boats have gone there from Plymouth.

During the last three summers some Plymouth smacks have gone over to the south coast of Ireland to fish. In 1885 twenty-one boats went there, and they had considerable success ; but in 1886, although they report excellent trawling grounds and abundance of fine fish, they did not make as much money as the few boats which remained on the home grounds. This was partly owing to the calms which prevailed off the Irish coast during last summer, and the inability to trawl on that account, and partly to the fact that the few boats (only thirty) which remained in Plymouth found a ready sale for the limited supply of fish they brought to market.

When the boats fished off the Irish coast they clubbed together, and divided equally the proceeds of their fishing. Some of the company were fitted with bunkers, in which the fish was packed in ice, and they were used in turn to carry the fish from the fishing ground to Plymouth.

Although as a rule the trawlers are engaged in fishing all the year round, yet in summer time some of them are used as small coasting cargo boats, chiefly for the carriage of potatoes between Ireland, Scilly, and Tenby.

Trawling Grounds.- The trawling grounds in the neighbourhood of the port may be grouped into two districts, the one within a line drawn from the Eddystone to Dodman Point, the other outside that line. A line of rocks runs between these two points, over which it is, except in a few places, impossible to trawl, and thus forms the two districts.

It is, of course, essential that trawling grounds should be free from rocks or other obstructions, wrecks, \&c.; and, indeed smooth ground, if it is formed of rock and not covered with sand, will chafe and tear the net, and cannot be trawled over.

Variation of Condition of Ground.-The condition of the inner ground trawled over varies greatly, according to the time of the year.

During the summer months, when there is but little wind and sea, the trawling ground becomes covered with sand and mud, masses of seaweed and beds of so-called "scruff ;" the latter are composed of a few oysters in clumps, great quantities of pecten, and polyzoa (Mucronella and Salicornariadæ I have seen in very considerable masses hauled up in the trawl), to such an extent in fact, that the trawl net is sometimes unable to bear the weight when being hauled out of the water and breaks away with all it contains. In the late autumn, winter and early spring months, on the other hand, when storms are prevalent, the ground becomes cleared of these obstructions and after trawling for six or eight hours the net may be hauled in with not more than one or two cwt. of débris.

This frequent alteration of the bottom of the sea, causing as it does variation in the kinds of fish caught and in the invertebrate Fauna, will be of great interest to investigate. It may be added that most of the scruffs lie west of the Eddystone rocks and parallel to the coast line.

In the following account of the trawling grounds fished by the Plymouth smacks it must be understood, that the localities mentioned for each season of the year are the favourite fishing grounds for that season; but smacks are so dependent upon the wind and weather that it is not possible for them always to reach or remain on their favourite grounds.

It may be taken as a general rule that in a strong north wind the smacks fish near in shore; when the wind is strong from the north-east they choose ground east of the Sound; when strong from the north-west they take westerly ground. Southerly winds are the most favorable. The trawlers of Plymouth fish, with the rarest exceptions, in at least twenty fathom water; the average depth fished in is probably between thirty and forty fathoms, while fifty fathoms may be considered as the maximum. 


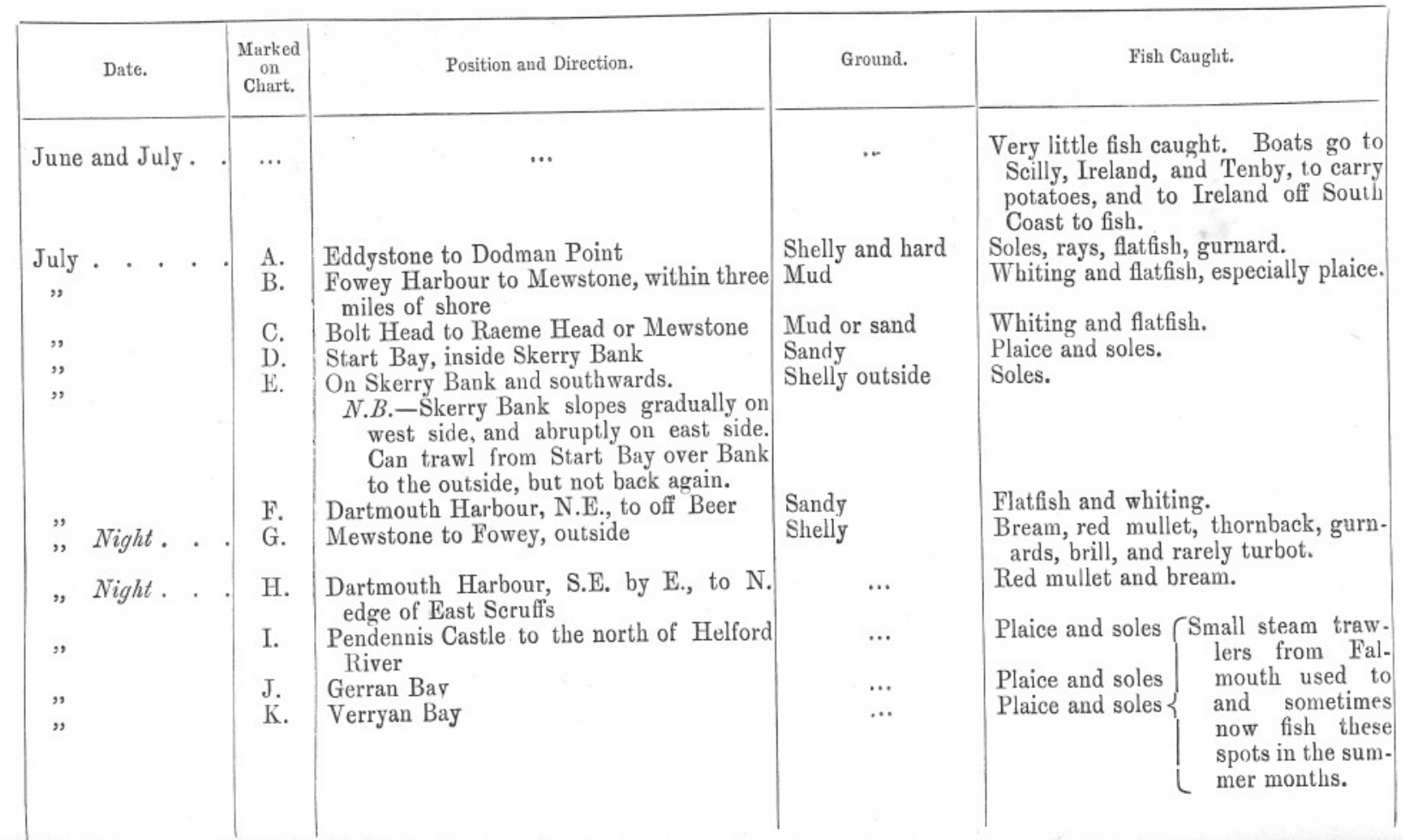

\begin{tabular}{|c|c|c|c|c|}
\hline Aug. to Christmas & $\begin{array}{l}\text { A. } \\
\text { to } \\
\text { H. }\end{array}$ & As given for July & $\begin{array}{l}\text { As for July, except } \\
\text { where midddy or } \\
\text { sandy or shelly } \\
\text { they become } \\
\text { clearer and har- } \\
\text { der towards last } \\
\text { months of year }\end{array}$ & Turbot and brill appear. \\
\hline Nov. to Christmas & L. & $\begin{array}{l}\text { East Rutts to Fowey Harbour, inside } \\
\text { Eddystone, or if wind will not serve then } \\
\text { outside Eddystone }\end{array}$ & Shelly outside & Hake now taken. \\
\hline $\begin{array}{l}\text { Christmas to Feb. } \\
\text { (end of Feb.) }\end{array}$ & M. & $\begin{array}{l}\text { Twenty to forty miles S. by E. of Plymouth } \\
\text { to point where Eddystone bears N.N.W., } \\
\text { trawl W. until open St. Anthony's Light } \\
\text { (Falmouth Harbour) }\end{array}$ & $\cdots$ & $\begin{array}{l}\text { Tub, sole, dory, brill, turbot, gurn- } \\
\text { ard, and ray. Long-finned gurnard } \\
\text { caught here. }\end{array}$ \\
\hline$"$ & N. & $\begin{array}{l}\text { Thirty miles S.S.E. of Start Point and } \\
\text { trawl E.nearly as far as Portland ("French } \\
\text { ground"), used by Brixham trawlers } \\
\text { chiefly }\end{array}$ & $\ldots$ & Mullet, ray, gurnard, and pout. \\
\hline $\begin{array}{l}\text { March to June } \\
\text { (end of June) }\end{array}$ & 0. & $\begin{array}{l}\text { Twenty miles S. and by E. of Michael's } \\
\text { Mount to Wolff Rock }\end{array}$ & $\ldots$ & $\begin{array}{l}\text { Common flatfish, gurnard, and ray, in } \\
\text { large quantities. } \\
\text { dory, and tubb. In Mot, brill, } \\
\text { taken. }\end{array}$ \\
\hline$"$ & $\cdots$ & $\begin{array}{l}\text { A few boats may fish over ground given } \\
\text { for July to Christmas, but nearly all shoot } \\
\text { nets only over ground mentioned above. }\end{array}$ & $\cdots$ & $\cdots$ \\
\hline$"$ & P. & Bolt Tail to Dodman Point. & $\cdots$ & Tub, red mullet, grey gurnard. \\
\hline
\end{tabular}


Trawl Fish.-The following is a list of the fish caught by trawlers which are used for food :

\section{Elasmobranchia :}

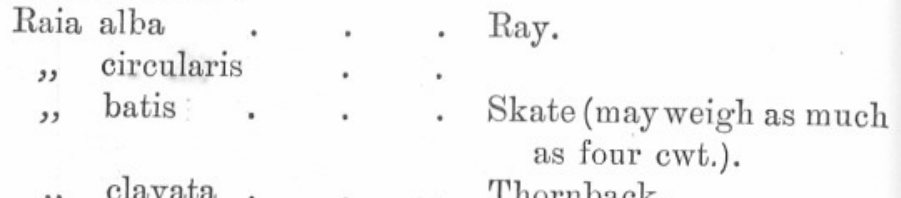

Teleostei.-Acanthopterygii :

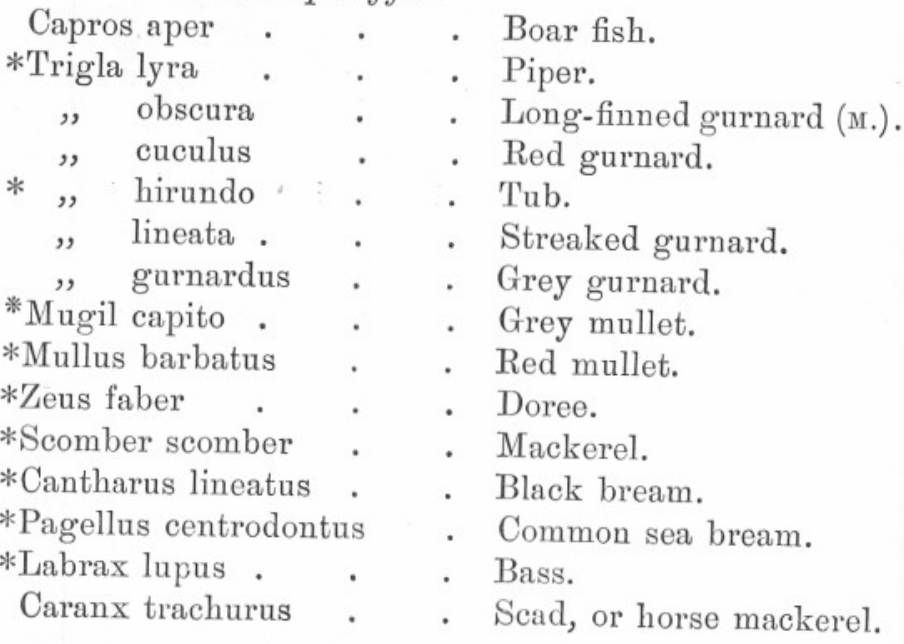

Anacanthini :

*Rhombus maximus . . Turbot.

* , lævis . . Brill.

*Solea vulgaris . . . Sole.

" lascaris. . . Lemon sole.

, variegata . . Thickback.

Pleuronectes limanda . Dab.

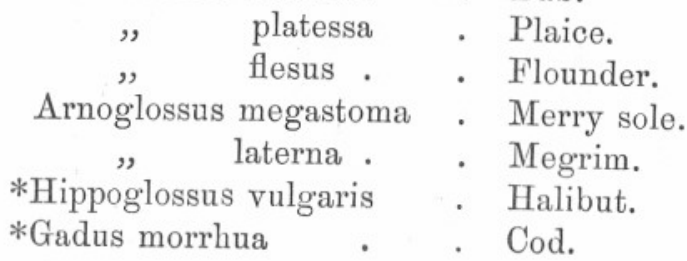

Anacanthini :

*Gadus æglefinus . . Haddock.

, pollachius . . Pollack.

, merlangus . . Whiting.

, luscus . . . Bib, or pout.

*Merlucius vulgaris . . Hake.

Molva vulgaris . . Ling.

Physostomi :

Conger vulgaris . . Conger.

Clupea pilchardus . . Pilchard.

„ alosa . . . Alewife, or shad.

Ganoidei :

Acipenser sturio . . Sturgeon. Generally two or three caught each year, Oct.-Dec.

Those marked with an $*$ in the foregoing list are considered to be "first-class" fish, "prime," or "head fish." The remainder are called "second-class" fish, "seconds," or "offal" fish, and are of less value than the former.

Movements of Fish-Summer and Winter.-With regard to the movements of fish, speaking generally, it may be said, fish draw near to the shore as the year advances from spring to summer. The summer fishing is carried on near to the land, and the trawlers haul their nets as near to the rocks as they dare to go.

In the winter months, and especially when snow falls, the fish go away into deeper and warmer water, consequently, the fishing ground is farther away from port.

Night and Day.-Again, fishermen say that at night more soles are caught than during the daytime, while round fish rise from the bottom at night, and therefore more are caught during the daytime than at night. During the day the soles and flatfish are believed to "sand" themselves, $i . e$. cover themselves over with sand.

In the North Sea it is said that night fishing is more profitable than day fishing, because haddock (Gadus xgle- 
finus), cod (G. morrhua) and ling (Molva vulgaris) rise from the ground during the daytime and sink again at night (No. 1).

As a rule in the Channel but little flat fish is found on shelly ground.

Effect of Storms.-It is a matter of general remark among trawlers that immediately after heavy south-west storms, the fish ordinarily caught on the trawling grounds in fine weather, between the Eddystone and Raeme Head and to the eastward, are not to be found there; their place being taken by rock-fish, conger (C. vulgaris), bass (Labrax lupus), bream (Pagellus centrodontus), pout (Gadus luscus), ling (Molva vulgaris), \&c., and with these fish larger quantities of kelp. It would appear probable that the rock-fish are driven from their usual habitat by the danger of the force of the water upon the rocks, and seek safety on smooth ground (the trawling ground), but with regard to the fish usually found on this ground (flatfish, gurnard (Trigla), mullet (Mugil capito), whiting (Gadus merlangus), hake (Merluccius vulgaris), \&c.), which are not caught there for a short time immediately after such storms, the fishermen do not know what becomes of them, but assert they go into deeper water.

It must be noticed further that large soles and plaice, the finest of which are to be found near rocks in fine weather, are caught in increased numbers on the smooth ground away from rocks, after storms have occurred. Should this be true-and there appears to be no room for doubt that my informant, who is an experienced trawler, speaks correctly-it would follow that the effect of storms is felt at greater depths than is usually believed.*

The depths of the rocks from which the conger, ling, \&c., have been driven is, say from ten to thirty fathoms. But from depths of forty fathoms, stones, lumps of coal, \&c., are brought up in the trawl, bearing every appearance of having been in constant movement, while trawls which have been lost in

* It has been calculated (No. 13) that a wave 300 feet long, and 6 feet from crest to trough, will cause an alternating current of 2 feet a second on the ground at a depth of six fathoms. that depth of water in heavy weather, have been found a considerable distance from the place where they were lost, with their " runners" bright as if they had been towed along.

Bellamy (No. $3 b$ ) states the effect of south-west storms is to drive the generality of fish to deep water.

Breeding of Fish.-Of the breeding habits of fish there is but little known by the fishermen. From June to October Whitsand Bay is found to be full of small young flat fish of various kinds, and would appear to serve, if not as a breeding ground for these fish, at any rate as a nursery for their young during these months. Soles are taken full of roe about March near Plymouth, and in April and May in Mounts Bay.

Besides fish the trawlers catch the following marketable commodities :

Crabs (Cancer pagurus).-Sometimes caught in considerable numbers, more by night than by day, however. The fishermen believe it buries itself in the sand during the day. Squid (Loligo).-Caught in very considerable numbers; it is the favourite bait of the hook and line fishermen.

"Queens" (Pecten).-They are used for food and bait. During calm summer weather they are brought up in the trawl in very great numbers.

\section{Drift-net Fishing.}

There are not a great many "drift-boats" owned in Plymouth, although a considerable trade is carried on, on the fish quay, in drift-net fish landed here from boats belonging to other ports. The centre of the drift-net fishery in the west country is at Penzance.

Boats.-From Plymouth about twenty boats, averaging, say, twenty tons each, sail regularly to fish for mackerel (Scomber scomber), or herring (Chupea harengus) or pilchard (Clupea pilchardus). These boats are lugger-rigged, and are manned by a skipper, four hands and one boy.

Besides these there are, say, twenty-five smaller boats, "hookers," between ten to twenty tons each, dandy rigged and manned by a skipper and three men, which fish with a few 
drift nets for herring and pilchard during the season when those fish frequent these shores.

During the herring and mackerel seasons there may be from 150 to as many as 300 or 400 sail, belonging to other ports, which bring their catch to Plymouth each day.

Fishery.-Drift fishing is carried on at night; the early part of the night and the very early morning, being considered the best times.

Shooting Nets.-The nets, which vary in size and size of mesh according to the kind of fishery, and even of the district fished, when "shot," lie to windward of the boat; they are buoyed and weighted in such a manner that they hang straight down from near the surface and drift with the current. The boat to which they are attached drifts with the nets, sail being taken off, and when heavy mackerel nets are used the mast is "stepped."

As the boat lies to leeward of the nets, and the wind acts more on the boat than on the nets, the former drifts faster than the latter, and so hauls them "taut." The nets hang like a wall in the water, and the fish coming against them try to swim through the meshes, and are caught by the gills.

The method of "shooting the nets" among Plymouth boats is as follows:-The nets are shot on the lee side of the boat while it is going before the wind. Eventually the boat brings up to leeward of the nets, generally arranging they shall lie on the starboard side.

Method of Fishing.-The nets are shot about sunset, and an hour or so afterwards the first one or two nets are hauled in to see if there are any fish in them. Should fish be about they may be left until near daylight, or hauled about midnight and shot again, and again hauled in before daylight. If fish are not in the nets when they are examined they haul them in and cruise to find a better place, and may shoot and haul the nets several times before finding fish.

"Briming." - In summer, at times when there is no moon, the fish may be found by the phosphorescent light they cause when disturbed.

The boats cruise about, and every now and then the men jump heavily on the deck. If fish are near, this disturbs them, and they can be traced darting along far down in the water by means of the phosphorescent light which their movement causes in the small marine organisms. This light is at times so brilliant, that it actually flashes through the water, and is reflected onto the sails of the boat. The phosphorescence is locally known as "briming."

Nets Made.-The drift nets are not made, or "bred" as it is called, in Plymouth; they are obtained chiefly from Porthlevin, Bridport, St. Ives, and Scotland. They are made of cotton, and are sent from the manufacturer "white." The fisherman then treats them in one or other of the following ways:

Nets Prepared.-They are first steeped in a hot solution of catechu for one to twelve hours, and dried by being squeezed between two rollers (as in a mangle). They may be steeped and then dried in this way three or four times. They are then steeped in a hot solution of tar and dried in the air. After going through the tarring process they may be tanned in bark liquor as much as three or four times before being used. This latter tanning process is gone through once perhaps every two months, or even less, according to the amount the nets are used.

Mesh.-The sizes of the mesh of the different kinds of nets used and their lengths, vary in different ports of the west country. Unless, therefore, a port is specially mentioned in the following accounts of nets, they must be considered as referring to Plymouth only.

\section{Mackerel Fishing.}

Time of Year.-Mackerel fishing is carried on nearly all the year round, from January to June, and then again from September to November. There may be an interval of eight or nine weeks in the summer during which mackerel are not caught, but often this time is reduced; the late fishing, on the other hand, may, instead of lasting three months, be continued only two or three weeks.

As a rule, but few fish are caught during May and June, 
but the supply and the time the fish arrive off the port vary greatly each year.

Boats.-Besides the boats of the port, boats which hail from other ports, and which land mackerel here during the time of year when they are most plentifully caught in the neighbourhood, may be estimated at 150 to 400 .

The ports from which they sail are as follows:

East Country Boats.-Yarmouth, Lowestoft, Brighton, Folkestone, Rye, and Newhaven.

West Country Ports.-Looe, Mevagissey, Falmouth, Porthleven, Newlyn, Mousehole, Fowey, Penzance, and St. Ives.

A few boats also come from Guernsey, Scotland, and the Isle of Man.

Nets.-The mackerel nets in use here are three fathoms deep, and the mesh $1 \cdot 44^{\prime \prime}$ to $1 \cdot 38^{\prime \prime}$ across, or twenty-five to twenty-six meshes to the yard.

Cornwall boats fishing for mackerel off Scilly use nets with a mesh of $1 \cdot 44^{\prime \prime}$, or twenty-five meshes to the yard; but many boats in other ports and some in Plymouth use nets whose mesh is $1 \cdot 3^{\prime \prime}$ across, or twenty-seven to the yard.

Each boat shoots sixty to eighty nets of sixty yards each; that is to say, a "fleet" of nets is two to three miles long.

Nets "Shot."-The nets are buoyed by corks at intervals of about a yard, and, because mackerel swim high in the water when in shoals, the top or "back" of the net lies nearly upon the surface of the sea. It is on account of the mackerel nets lying so near the surface, and in consequence of the great length of net "shot," that great losses are experienced in this fishery. A sudden storm may almost completely ruin a fleet of nets, and a steamer or vessel cuts through them frequently.

In order to be able to recover nets which have been so cut through by vessels, a line, the "foot-line" by which the nets are hauled in, is attached to each net, and hangs six fathoms below them. This line, being 54 feet below the surface, is well out of reach of any vessel's keel.

Fishing Grounds.- The ground fished by boats bringing their catch to this market may broadly be stated to be, the whole extent of water from the coast between Start Point and Dodman Point to a parallel line drawn, forty miles south of the coast.

Winter Fishing Ground.-In January (i.e. during the "winter fishing"), as a rule, the boats go to the ground furthest away from the coast; as the season advances the fish approach the shore, and the fishing is nearer home.

Summer Fishing Ground.-During the "summer fishing" season the fish are generally found from four to twelve miles from the coast.

The early fishing is to the eastward, the late fishing to the westward of the port.

It will be understood these remarks are only approximately correct, owing to the variable supply of fish and the somewhat irregular course of their migrations.

Fishery Productive.-This fishery appears to be very productive, and no falling off in the supply of fish is, I believe, reported.

\section{Herring Fishing.}

The herring fishing for this port lasts from November to the end of January.

Boats.-The boats from other ports, which may number about 200, fishing here at this time hail from west country ports.

Nets.-The herring nets are each 120 yards long and three fathoms deep, twelve nets forming a "fleet," which is, therefore, nearly a mile long. The mesh is $1.125^{\prime \prime}$ or $1.058^{\prime \prime}$ across, i.e. thirty-two to thirty-four meshes to the yard in some cases; many boats, however, use smaller meshed nets, about $\cdot 97^{\prime \prime}$ across or thirty-seven meshes to the yard. This latter is about the mesh used for pilchards, and these nets are practically pilchard nets, and may be used to catch both fish.

Nets "Shot."-The nets are buoyed at intervals of five to seven fathoms, and the "back" of the net lies about three and a half fathoms below the surface; this distance is varied, however, according to the depth of the water fished and the depth at which the shoals are swimming.

On account of the depth at which the nets lie, and their consequent safety from accident by being cut by passing 
vessels, it is not considered necessary to provide for their safety by hanging a foot-rope below them. The "foot-line", lies, therefore, on the "back" of the net.

Another reason and one which renders this arrangement of the foot-rope necessary is, that at times the water fished is so shallow that the nets themselves have to be hauled nearer the surface (the lines by which they hang from the floats being shortened), to prevent them dragging along the bottom.

Fishing Grounds.-The grounds fished extend from the Mewstone to Bolt Tail from one to eight miles from the shore.

Fishery - For the last two years this fishery has not been so good as usual.

\section{Pilchard Fishing.}

The pilchard fishery is very variable in extent, and the times during which it is carried on is also quite uncertain.

If there is a good supply of fish it lasts about from July to Christmas, and is divided into two sections :

1. A summer fishery, lasting during July and August.

2. A winter fishery, from September to Christmas.

Boats.-Besides Plymouth boats, about 120 small boats belonging to west country ports, Mevagissey, Falmouth, Looe and Polperro, bring fish to this market.

Nets.-The pilchard nets are each 120 yards long, and a fleet consists of twelve to fifteen nets forming a line of nearly a mile in length. They are six fathoms deep, and those used for the summer fishery have meshes $95^{\prime \prime}$ across or thirty-eight to the yard, while those used for the winter fishery have meshes $1^{\prime \prime}$ across or thirty-six to the yard. Old shrunken herring nets are frequently used for the pilchard fishery.

Fishing Grounds.-The grounds fished are as follows :-

1. During the summer fishery, between Raeme Head and Looe Island, near in shore. The fish work their way eastward towards the autumn; and

2. During the winter fishery the nets are shot off Plymouth, and, may be, as far east as off Bigbury Bay, but chiefly from seven to eight miles south to south-south-west of Plymouth Sound.
Condition of Winter Fishery.-For the last two winter seasons pilchards have been now and then so cheap on the quay, that fishermen have taken their catches out to sea and thrown them overboard rather than sell them for the small sums offered. They have been sold as cheap as 2 s. per 1000 recently, and indeed, now (November, 1886), boats are fishing with only half a fleet of nets in order to reduce the catch and keep up the price of the fish. These boats are endeavouring, by fishing with hook and line for hake, to make their work pay.

Condition of Summer Fishery.-The summer fishery for pilchards, on the other hand, has largely decreased in Plymouth. It has been taken out of the hands of the Plymouth fishermen by the fishermen of Looe, whose boats appear to be more suitable for the work. At this latter port the increase of boats in the last few years is estimated at 30 per cent.

\section{Moored-net Fishing.}

Boats.-There is but little fishing of this description practised by Plymouth boats. A few of the line fishing boats during the herring season carry on moored-net fishing. These are chiefly Cawsand Bay boats.

Nets.-The nets are similar to drift nets; but instead of drifting with the tide, they are moored by means of grapnels, and are "shot" in the direction in which the tide runs.

Fish.-The fish caught is the herring.

Ground Fished.-The ground where the nets are set is almost confined to the mouth of Cawsand Bay.

\section{Seine Fishing.}

Seine fishing is carried on all down the coast as far as Land's End. The seine is used to catch mackerel, pilchards, sprats (Clupea sprattus), and mullet (Mugil capito), but not herrings.

The great centre for this method of fishing is at St. Ives, on the west coast of Cornwall.

There are several kinds of seines.

Seine Proper.-The seine proper is a long net, deeper in the middle or "bunt" than at the ends ("sleeves" or VOL. I, NO. I. 
"wings"). A large seine is about two hundred fathoms long and ten fathoms deep at the " bunt."

Method of Fishing.-It is carried in two boats, which lie in wait for shoals of fish near the land.

The fish are, during the time this fishery is carried on, swimming near the surface of the water, and a shoal is readily observed by means of the colour, or, especially in the case of pilchards, by the oily appearance of the water covering them.

The two boats row round the shoal, or as much of it as the length of their net will allow them to compass, shooting the net as they go; the two ends of the net are bronght together and it is hauled to the shore, where it is moored, the fish contained therein being taken out as required with smaller seines called "tuck seines."

Tuck Seine.-A tuck seine is, say, seventy fathoms long, but much deeper in the "bunt" than an ordinary seine, so that it may be hauled in under the fish and raise them to the surface, to enable the men to get them out of the water.

Ground Seine.-A third kind of seine, the ground seine, is used here. It is much smaller than the seine proper, and is used close to the shore. A rope attached to one end is left on shore, a boat then rows in a semicircle, and the net is shot as the boat goes along. Finally, both ends are brought ashore and the net hauled bodily on to the land. These nets may be quite small, and are readily worked. Their structure, although differing in detail, is very similar to the large seine.

Mackerel Seining.-Mackerel seining is carried on from June until the end of July all along the coast from Start Bay to Land's End. Most of the seines here are owned in Cawsand, at the mouth of the Sound. This is a favourite place for carrying on the fishery, and there the seine boats, full of nets, may regularly be seen lying near the mouth of Cawsand Bay, waiting for a shoal of fish.

Pilchard Seining.-Pilchards are seined during the summer. At Cawsand this fishery is carried on on a small scale.

It is said that some years ago the pilchard fishery at Cawsand was conducted on a very considerable scale, and the large cellar accommodation in some of the houses of the village is a partial proof of this; now, however, there is but little business done. All along the coast, from the Land's End to the Lizard, this fishery is conducted, and at St. Ives it is an important industry.

Mullet Seining.-Mullet seining is carried on up the estuaries all through the autumn.

Sand Smelt Seining.-Sand smelts (Atherina presbyter) are seined in the estuaries about September.

Sprat Seining.-Sprats are seined both in the Sound and along the coast.

Ground Seine Fish.-Ground seine fishing is carried on along the rocks of the Sound at low water, bass (Labrax lupus), mullet, \&c., being caught. These nets are from about twenty to fifty fathoms long.

\section{5. "Bultering" or Long Line Fishing.}

Boats.-There are, say, sixty boats following this method of fishing. They are mostly about twelve tons, are "dandy" rigged,* and manned by a skipper and three men.

About thirty-five of these boats regularly fish with long lines, but the remainder, say twenty-five and these are the largest of the fleet, fish for herring and pilchard with drift nets during the season these fisheries are carried on here. These boats carry only a small "fleet" of drift nets, suitable for herring and pilchard, and do not fish for mackerel.

Besides the home bulterers, boats from Looe, Polperro, and other ports in the neighbourhood bring fish to this market at times.

"Bulters."-The bulterers fish by means of long lines or "bulters," of from about 2500 fathoms length and less. To these lines hooks are attached at intervals of $1 \frac{1}{2}$ fathoms, by means of "snoods" about 3 feet long, made of strong fishing line. There are therefore about 1666 hooks on a line 2500 fathoms long.

Lines "Shot." - The lines are "shot," or laid down at

"A "dandy" rigged boat is somewhat similar to a yawl, but differs in it is stepped the most obvious of which are the position of the mizzenmastit is stepped right aft-and the kind of sail which it carries-a lug-sail. 
right angles to the direction in which the tide runs, so that the snood carrying the hook may be washed free from the main line, and they are attached at either end to buoys of cork, which carry a flag to show their position.

Times of Fishing.-The lines are " shot" at any time after sunset, left for some time, and hauled in again when the several directions of the wind and tide render it possible to do so. A "weather-going tide," as it is called, is necessary to enable these long lines to be hauled in, $i$. $e$. a tide which runs against the wind. A "lee tide" is one running with the wind, and the bulter cannot be hauled in while such a combination of forces lasts. On this account much delay may be experienced.

Plymouth Bulters.-The Plymouth bulters use longer lines than any other boats on this portion of the coast, but the North Sea long-liners use much longer lines than they do here. A North Sea bulter may be 7200 fathoms long and carry as many as 4680 hooks (No. 11).

Lines.-The lines in use here are obtained from various places in Ireland and Scotland, and from London, as well as from local manufacturers. They are generally used in the same condition as they arrive, but they may be "barked" or "tarred." They are made of manilla or of sisal, an imitation of manilla.

Hooks.-The hooks are supplied from France or from Redditch.

Grounds Fished.-The grounds most frequented by the bulters with the longest lines are situated:

1. Far out in the Channel, from a point forty miles south of the Eddystone to a point twenty to thirty miles south of the Lizard.

2. Close to the land in the region of the Lizard and even round Land's End, and as far north as St. Ives.

3. Off Start Point, from fifteen to twenty miles south.

These boats also visit Guernsey, Brighton, and other places for a few weeks at a time to carry on their trade.

The smaller bulterers with shorter lines, shoot the latter all along the coast both west and east of Plymouth Sound, and round about the rocks of the Eddystone, the Hand
Deeps, and in places along the line of rocks extending from the Eddystone to Dodman Point, which I have already mentioned (p. 8) in my account of the trawling grounds in this neighbourhood.

The ground fished in mid-channel is composed of rubble, the stones being about half the size of a man's head, or thereabouts, and is locally known as " titi" ground.

The bulterers can shoot their lines upon this class of ground without fear of being disturbed by the trawlers, the ground being too rough for them.

Near home, where the exact positions of large rocks are known, and when the weather is clear enough to enable the fisherman accurately to take his marks, the lines are shot as near as possible to these rocks, and probably the finest fish are caught in these spots.

Fish Caught.-The following fish are those usually caught by this method of fishing:-Conger (Conger vulgaris), ling (Molva vulgaris), ray and skate (Raia alba, circularis, batis, and clavata), cod (Gadus morrhua) in small quantities, and a few pollack (Gadus pollachins).

Bait. - The bait used by bulterers is chiefly squid (Loligo); but they also use pilchard, mackerel, herring, garfish (Belone vulgaris), whiting (Gadus merlangus), gurnard (Trigla), chad (the young of Pagellus centrodontus), bream (Cantharus lineatus), and dogfish (Scyllium canicula); according to the season and in case of scarcity of squid.

During the spring-about Lent-when many trawlers are fishing in Mount's Bay, and there is but a small supply of squid and great competition for what there is to be sold, the bulterers fall back on "fish-baits," and pilchard is perhaps the best of these.

At this time of year the long-line fishermen even go as far as Falmouth, Mevagissey, Looe, and other ports along the coast to buy bait.

Price of Bait.-The price of bait varies very greatly. Squid, when very plentiful, may be as low as $6 d$. a maund, but during Lent has been known as much as $12 s$. a maund. Pilchard in the same way varies from $6 d$. to $5 s$. per 100 .

Amount of Bait Used.-Some idea of the amount of bait 
which might be used may be gathered from the fact that it takes 1000 pilchards or six maunds of squid to bait a long bulter. A maund of squid will weigh, say, $56 \mathrm{lbs}$.

Say sixty boats average 2000 fathoms of line, i.e. 1333 hooks per boat. They will consume 288 maunds of squid or say $144 \mathrm{cwt}$. (over seven tons) in baiting their lines.

\section{Value of Bait Used.-}

This amount represents in value at $6 d$. a maund . $\quad . \& 4 \quad 4 \quad 0$

$$
\text { " " } \quad 12 s . \quad \text {. . } 172160
$$

or, they will use 48,000 pilchards, which represents in money-

$$
\begin{array}{llllll}
\text { at } 6 d \text {. per } 100 & . & . & £ 12 & 0 & 0 \\
\text { at } 5 s . \quad, \quad & . & . & 120 & 0 & 0
\end{array}
$$

In the case of a single boat. When squid are cheap it costs $3 s$. to bait a long bulter with 1666 hooks, when dear $£ 312 s$, whereas pilchards cost from $5 s$. when cheap to $50 \mathrm{~s}$. in the dearest times, to bait a long bulter.

An average is not easy to calculate, but from the accounts of two hookers which have been very kindly submitted to me, it appears that about $£ 100$ a year per boat is spent on bait ; that is to say, bait for sixty boats of the same size for the year would cost $£ 6000$.

Making allowance for boats laid up at various times, the smaller size of some boats, and the fact that certain of them do not use their lines all the year round, the sum spent on bait for the year by Plymouth boats may be estimated at not less than 14500 . The bait question is therefore a serious one.

Squid (Loligo).-The supply of squid depends, as I have stated, upon the trawlers. After a spell of rough weather the hookers having no bait must wait until the trawlers can go out and bring some, then if calms or storms should at once come on the bait spoils, and again when fine weather comes they have to wait until the trawlers have made a trip and brought in bait before they can go out to fish.

This obviously entails great loss of time and money, and renders the bait question one of extreme importance for the hooking trade of the port.

Attempts have been made to preserve squid in salt or ice but they do not appear in this condition to attract the more valuable fish, conger. This fish, contrary to the general opinion, appears to be a very particular feeder. It will take into its mouth and bite, but as a rule ultimately reject, any but fresh bait.

Whelks (Buccinum undatum).-Whelks are not found here in abundance and do not occupy the important position among bulter baits here that they do among the North Sea cod fishermen. They are tough and make excellent bait for bulters. It must be recollected that, owing to the length of time the bulter is under water, quite a different kind of bait is required for this fishery to that required for the hand-line fishery. Mussels (Mytilus edulis), "queens" (Pecten), and such soft bait is only of use on hooks that are let down into the water and pulled up again in a few minutes ; a prolonged immersion would render them too soft for the hook to hold them, and even a comparatively short time on a bulter-hook is enough to render them unattractive as bait.

Condition of Fishery. - With regard to the condition of the bulter fishery the men consider they do not catch as much fish now as they used to do twenty or even eight years ago, although their gear is eight times as long as it used to be, and the boats are larger, better, and more numerous. It is their opinion this is due to over-fishing, and as a proof of this they point out that very much smaller conger are exposed for sale on the Quay now than used to be the case. It is said that Plymouth is more deeply interested in this fishery than is any other port in the west country.

\section{Hand-line Fishing.*}

Boats.-There are, say, 110 small boats, most of them under five tons, and 100 small rowing boats under one ton, engaged in this fishing.

As a rule they fish for particular kinds of fish, going to particular grounds for the various kinds of fish according to the time of year, tide, weather, and so forth.

Hand Lines, Bottom Fishing, Railing or Whiffing.-The

* Besides the information derived from practical fishermen included in this section of my report, I have freely used the publications of Bellamy (No. 33, $b$ ), Lord (No. 17), Young (No. 25), Wilcocks (No. 24), and Brooks (No. 5). 
fisbing is carried on by means of lines held in the hands and let down from the boat, in the case of bottom fishing when the boats are anchored; or held in the hand or fastened to rods which are fixed, in the case of " railing " or "whiffing," when the boat is sailed or rowed through the water. The latter method is used for fish which are feeding near the surface, as do the mackerel when the shoals have broken up.

Whiting Fishing (Gadus merlangus).-The most important hand-line fishery carried on here is the whiting fishery.

Season.-It commences about April, or may be earlier, and lasts until the end of the year.

Boats.-Between Christmas and April, many of the larger hand-line boats are laid up-(in Cawsand at the entrance to the Sound, which is almost altogether a whiting fishing village, nearly all the boats are laid up) -and the hands ship in hookers, or go fishing with crab pots in smaller boats. A few of the larger boats, however, fish for herrings with a few herring drift nets during these three months.

Ground.-The whiting ground may generally be said to be from seven to ten miles outside Plymouth; but these fish are canght anywhere from a point outside the Mewstone from which one can see well up Yealm Gut, to twenty miles away.

In spring the ground frequently taken lies south-east of the Eddystone ; later on in the year the fish are to be caught north-east of the "Stone." Small whiting are very generally caught in the Sound.

Time of Year.-The fishery lasts from April to Christmas. Bait.-The chief bait used is mussels (Mytilus edulis), lugworms (Arenicola piscatorum), pilchards (Clupea pilchardus), mackerel (Scomber scomber), garfish (Belone vulgaris), and other kinds of fish, such as chad (young of Pagellus centrodontus).

Hake Fishing (Merlucius vulgaris).-Great numbers are taken with hook and line during the winter pilchard fishery, when these fish can be obtained readily for bait. It is a frequent occurrence for drift fishermen while their nets are out for pilchards to fish with hook and line for the hake which come in search of the pilchard. These fish feed, and therefore take the hook best, at night. They vary from 5 to $12 \mathrm{lbs}$.
Haddock Fishing (Gadus æglefinus).-When fishing for haddock with hand lines the best bait is squid with a large mussel on the point of the hook.

Cod Fishing (Gadus morrhua).-The codfish caught here are comparatively few, and they are not to be compared ith the North Sea cod for either condition or flavour.

Bait.-The best bait to use is squid, mackerel, herring, or pilchard.

Pollack Fishing (Gadus pollachius).-Ground in the Sound.The positions in the Sound and its neighbourhood where pollack are found are numerous.

1. On the east side all along the shore at a depth of about

1. "Mewstone," "Leek Beds" and "Batten Bay."

2. On the north side under the "Hoe," and between "Drake's Island" and the main land.

3. In the Hamoaze at the "Pollack Rocks."

4. On the west side all along the shore (except far in Cawsand Bay) and round Penlee Point, especially at Barn Pool, and off "the Bridge," Picklecombe Point, and Penlee Point.

5 . On the south side from " the Tinkers" to the east end of the Breakwater. From the "Knap" Buoy round the west end of the Breakwater and along its south side.

Movements of the Fish.-The majority taken within the Breakwater are small fish; mature fish ( $2 \frac{1}{2}$ to $10 \mathrm{lbs}$.) are taken only at certain times. From spring to midsummer are the off the Mewstone and the Tinkers, until the higher temperature drives the fish to deeper water, where they are caught in the offing; they visit the shallows only at intervals.

In September, the large fish return to the shallows and in autumn are caught especially in Barn Pool and between Drake's Island and Mill Bay in twenty-three fathoms of water. The largest fish caught in the harbour, are, as a rule, caught at night.

Bait - The best bait for ground fishing is living sand-eels (Ammodytes lanceolatus and tobianus); the professional fisherman uses the rag-worm (nereis) generally. For whiffing artificial baits are used. 
Rod and Line Fishing.-Pollack fishing is also carried on off the rocks, when rock-fish or sand-eels are used for bait, with a rod and line.

Time of Year.-Pollack fishing commences in May and continues throughout the fine weather.*

Mackerel Fishing (Scomber scomber).-Ground.-The best places for ground fishing are from Batten to Bovisand, and in the Hamoaze.

Bait.-The bait used with the greatest success is pilchard, squid, and mussels.

Whiffing.-The positions for mackerel "whiffing" are the same as those given on the map for pollack.

Railing.- "Railing" for mackerel is carried on in the summer. The boats are sailed about three miles an hour.

Bait.-The best bait appears to be some shining object, such as slips of tin or attractive pieces of cloth.

Bass Fishing (Labrax lupus).-Lod and Line.-Bass are fished for with rod and line off the rocks at Raeme Head, Penlee Point, Bottle-nose Point, and at either end of the Breakwater, by throwing out the line, to which is attached a spinning bait, and drawing it back along the surface.

Bottom Fishing, Bait.-Bottom fishing is carried on also for bass with squid or pilchard, or sand-eel for bait.

Times of Year.-Bass enter the harbours in summer. July is the best month for fishing, but they are caught up to the end of September. Outside the Sound the fishing off the rocks begins about May.

Whiffing. - Whiffing for bass is carried on over the same ground marked on the map, frequented by fishermen of pollack and mackerel.

Pouting Fishing (Gadus luscus).-Time of Year.-Pouting are in their best condition in November and December, but are taken all through the winter and in spring. The best places to fish for them are :

Grounds.-The Mallard Buoy, near Mount Batten at low water or on the flood tide. West Hoe Terrace during the

* For positions, see fishing map (p. 76). The dotted lines represent the best courses for whiffing, the crosses and stars the best places for ground fishing. flood tide. Near the White Buoy, at the east end of Drake's on the top of the flood tide. At Millbay Pier at low water. In a deep pit off the "Flat Rock." In Firestone Bay, on a flood tide. In Cawsand Bay, and off Boviand Pier. Inside the Breakwater along its west half, and by the Panther Buoy. Bait.-The baits generally used are sea-w "tail end" of cola piscatorum and Nereis), mussels, and the "tail end" of the hermit crab (Pagurus).

Bream Fishing (Pagellus centrodontus and bogaraveo).Grounds.-Bream are caught on the whiting grounds.

Bait.-The best baits are rag- or lug-worms, sand-eel, mackerel, pilchard, herring, mussel, or limpet (Patella vulgata). Chad Fishing. (Pagellus centrodontus, Young Sea Bream.) - Time of Year.-Chad fishing begins in August.

"Float Line," and Bottom Fishing.-They are fished for "Float Line, and Bor the surface with a "float line," and when swimming bottom also.

are fished for on the grounds mostly frequented are: A short distance due south of the Round Fort at the Breakwater ; at the "Knap Buoy," "Penlee Buoy," and "Shagstone." Fish Caught by Hand Lines.-The fish caught by hand lines are therefore :-By bottom fishing:

Teleostei.-Acanthopterygii: Scomber scomber. . Cantharus lineatus . Pagellus centrodontus .

$\begin{array}{cc}\text { bogaraveo } & \cdot \\ \text { " } & \text {. }\end{array}$

- Mackerel.

Labrax lupus.

Anacanthini:

Gadus morrhua . . . Cod.

" æglefinus . • . Haddock.

„ pollachius • • . Pollack.

merlangus . . . Whiting.

"luscus. . . . Pouting.

Merlucius vulgaris . • . Hake.

By whiffing : pollack, mackerel, and bass. 
Fishing Map of Plymouth Sound, after map published in $C$. and R. Brooks's 'General Guide to Sea Fishing' (No. 5).

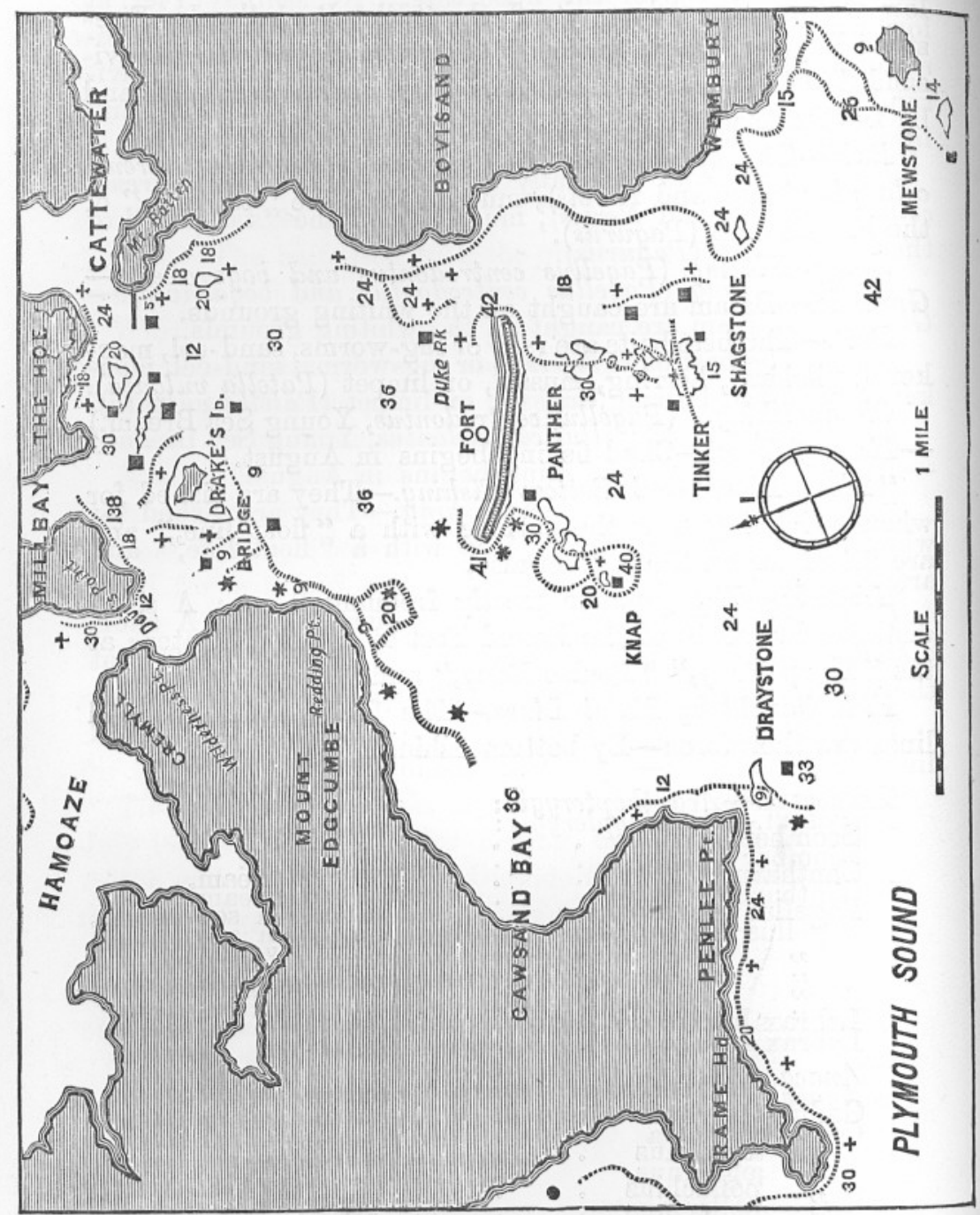

The depth is marked in feet thus 30 . The best places to fish for pollock, bass and mackerel is shown by the dotted line. The crosses show places to fish in ebb tide, the stars show places to fish in flood tide.
Bait.-The baits used for hand lines are: Fresh squid (Loligo), which is supplied by trawlers, this is the best; squid and salted squid are also used, but with little success; mussels (Mytilus edulis), obtained by a limited (nussel fishers from the bottoms of hulks, \&c., from beds up the Hamoaze, and from off the stones of the Breakwater; "queens" (Pecten), supplied by the trawlers in large quantities in summer; mackerel (Scomber scomber), herring (Clupea harengus), and pilchard (Clupea pilchardus), drift fishermen; garfish (Belone vulgaris), obtained from drift fishermen generally; chad (Pagellus entrodontus), \&c., fished for with hand lines ; sand-launce or sand-eel (Ammodytes lanceolatus and A.tobianus), obtained by raking the sand at low water, or in some places by eining, an excellent bait; hermit crab (Pagurus), the soft part of the body of the animal is used; white sand-worms (Nereis versicolor), and rag-worms (Nereis lineata?), two species of Nereis which are found in the mud of creeks, \&c., at low water, the latter is the favourite worm bait; linorm (Arenicola piscatorum), found by digging in sand at low water; and the earthworm (Lumbricus).

For whiffing the following baits are used: Strips cut me tail end of mackerel, herring, pilchard, garfish, chad, \&c. ; strips of the skin of bass, gurnard, ray, \&c.; strips of salt pork ; pieces of parchment, cloth, and tin ; but the band-launce, which is put on the the best bait of all is these hook alive. Artificial baits are being an imitation sand-launce made of india rubermen. is mostly, if not exclusively, used by are not used Mussel Bait.-It is noticeable that in the North Sea.

to the same extent here as they are in the connected with the

There is a very considerable incusty supply of mussels for bait in the North seall catch $£ 41,000$ culated (No. 8) that 1000 tons of mussels wing Nerth

worth of haddock, cod, and whiver storing, keeping alive, and An apparatus (No. 9) for storing, kussel farms infattening molluscs has been patented, anthern coasts of the stituted in several places on the ns kingdom, with, I understand, fair financial success. A 
before observed, the method of fishing by means of long lines (bulters) is not favorable to the use of soft baits like mussels; but it would appear that, for hand-line fishing in this district, fish and worms are more extensively used for bait than mussels.

Pecten.-Pecten and mussels may perhaps be considered to be fairly equally in demand. The former is considered to be a very fragile bait, but there is a good supply of it.

Condition of Fishery.-The condition of this fishery is, as far as I can learn, good. Excellent and large fish are caught plentifully on the whiting ground, which is the chief fishery.

\section{Eel-spearing.}

Eel-spearing is carried on in the mud of the Tamar in the early part of the year.

The eels (Anguilla vulgaris) come down the river to spawn in the harbour about August, and they hibernate about Christmas in the mud of the estuaries. There are, however, eels in the harbour which do not migrate and do not hibernate, and they are reputed to be the best and finest tasted (No. $3 a$ ).

\section{Mulletries.}

Some time ago several mill ponds communicating with the Hamoaze by means of gates were utilised as mulletries I am informed. The mullet (Mugil capito) were allowed to enter the ponds with the tide, and the gates were then closed and the fish caught with seines.

A pond, "The Mulletry," situated at Weston-Mill Lake, beyond Keyham, which is entirely cut off from the Hamoaze except by a sluice, has more recently been used for storing mullet; the fish being caught in the Hamoaze with a seine and placed in the pond until required for market.

Now, however, neither the mill ponds nor " The Mulletry" at Weston-Mill Lake are used commercially as fish ponds.

\section{Crab and Lobster Fishing.}

Ground.-Crab (Cancer pagurus) and lobster (Homarus vulgaris) fishing is carried on everywhere along the coast, mostly perhaps about Start Point. Off the Lizard there are one or two small steam launches engaged in this fishing.
Inside the Sound, and in deep water, up to thirty or forty fathoms, outside the Sound as well as along the neighbouring coast, the crab and lobster fishers of this port lay their pots. Pots.- "Pots" only are used.

Bait.-The bait generally used is gurnard (Trigla), wrasse (Labrus mixtus), and ray, gurnard being the best for lobster.

Time of Year.-Summer is the chief time for this fishery. In the winter months there is but little done owing to the loss of pots in bad weather. Inside the Breakwater the fishery may be carried on from February to November, rarely in the intervening months. Outside the Breakwater, in deep water, the pots are laid only from about April to August.

The male crabs are about six times more valuable than the female crabs.

Condition of the Fishery.-The crabs are said to be decreasing, but lobsters are not thought to be decreasing as much as crabs.

From 1850, when there were eight boats fishing between the Plym and Bolt Tail there was a considerable increase in the fishery up to 1876 , when there were 100 boats fishing this part of the coast. Since then there does not appear to have been much increase, if any. During this interval there has also been an increase in boats fishing in the Sound (No. 20).

\section{Shrimp and Prawn Fishing.}

Shrimps (Crangon vulgaris) and prawns (Palæmon serratus) are fished for in the Sound with small trawls, which are towed by small boats, either rowed or sailed slowly along.

The supply varies greatly according to the weather.

The chief ground is that lying immediately behind the Breakwater.

11. Oyster, Mussel, and Cockle Fishing.

Oysters (Ostrea edulis).--Very few oysters are now trawled in the Channel by the Plymouth trawlers. Sometimes, as I have already pointed out, a few clumps of oysters are brought up with the "scruff," which is so plentiful in the summer months.

Cattewater Beds.-Plym Beds.-There used to be oyster beds up the Cattewater, near Laira Bridge, up the 
Plym, and in Cattewater Harbour, opposite Queen Anne Battery, they used to be abundant; there are, however, no beds now - a few isolated oysters may be picked up here and there. This failure of the Cattewater beds is, by some, attributed to over-dredging, but it would appear more probably to be due to the refuse from china-clay works pouring down the river and choking the beds.

It is said (No. 2) that the mineral sand and clay, which is so frequently brought down by the South Devon rivers, forms, with the chemical constituents of the sea water, a compound which destroys oysters. Scott states, speaking of the Devonshire oyster fisheries, that in 1864 there were practically no Devonshire oysters, and he considers this due to over-dredging (No. 22).

Tamar Beds.-Up the Tamar, at the mouth of the St. Germains River, there are, however, still oyster beds, though I cannot learn that they are in a flourishing condition.

In the Sound.-In the Sound, opposite West Hoe Terrace, at the foot of the Hoe, oysters are being laid down for storage, I am told.

Mussels (Mytilus edulis).-Mussels are plentifully obtained from the hulks lying in the Cattewater and the Hamoaze, and from the stones of the Breakwater. They are also dredged in large quantities in the lower reaches of the Hamoaze, and are then bedded on a bank near Saltash Bridge.

Cockle Beds (Cardium edule). - Cockle beds exist both up the River Plym, near Laira Bridge (to the north of it), and on a bank bare at low water, which lies in the centre of the Tamar river, some little distance north of Saltash. Only a very small trade is carried on in these shell-fish.

II.-Industries connected with the Fishing Trade carried on in Plymouth.

This subject may be subdivided into-

1. Boat building. 2. Sail making. 3. Rope making and fishing-line making. 4. Net breeding. 5. Fish curing. 6. Fishskin curing. 7. Fish-oil manufacture. 8. Ice manufacture.

Boat Building.-The chief industry connected with the fish trade which is carried on in Plymouth is boat building; sail making and rope making is also conducted here on a sufficient scale to supply the boat builders.

Nets.-Nets for drift fishing are not "bred" here, but the trawlers themselves make their own nets.

Lines.-Lines for hooking are made here, but fishermen do not exclusively rely on local manufacturers.

Fish Curing.-Fish curing is carried on, on a small scale only, and would, in my opinion, be well worthy of the attention of capitalists.

Fish Slins and Oil.-A small trade is also carried on in fish skins and fish oil, but these are at present on a very small scale.

Ice.-An ice manufactory exists.

\section{Boat Building.}

There are about fifteen boat builders in Plymouth and Devonport. Six of these build trawlers, three build drift boats, five build hookers, and several build rowing boats.

Trawlers.-Trawlers are built in Plymouth, chiefly for the Plymouth fishery, but boats have been built for the North Sea, and for other ports on the south coast besides Plymouth. Only a few, however, have been so disposed of, and none have been bought out of Plymouth for some few years. Trawlers have been obtained for the Plymouth fishery from Brixham and Galmpton, but, as may be seen from the Table on p. 38 , only a few.

Trawler Measurements.-The following are the measurements of two recently built trawlers, and eight boats have been constructed of forty-two to forty-seven tons, with the same proportions. $*$

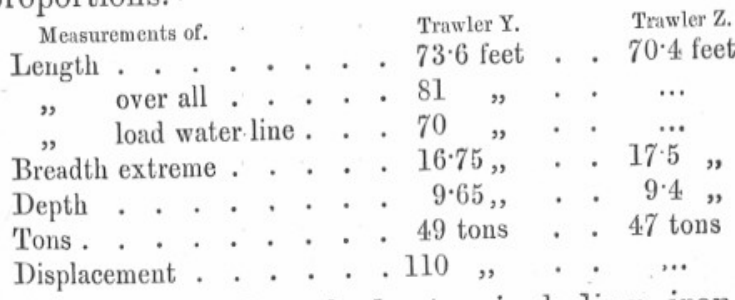

Cost.-The cost of such boats, including iron ballast spars, rigging, sails, and net, is from $£ 750$ to $£ 1000$.

* I am indebted to Mr. Watson (No. 34) for these measurements. voL. I, NO. 1. 


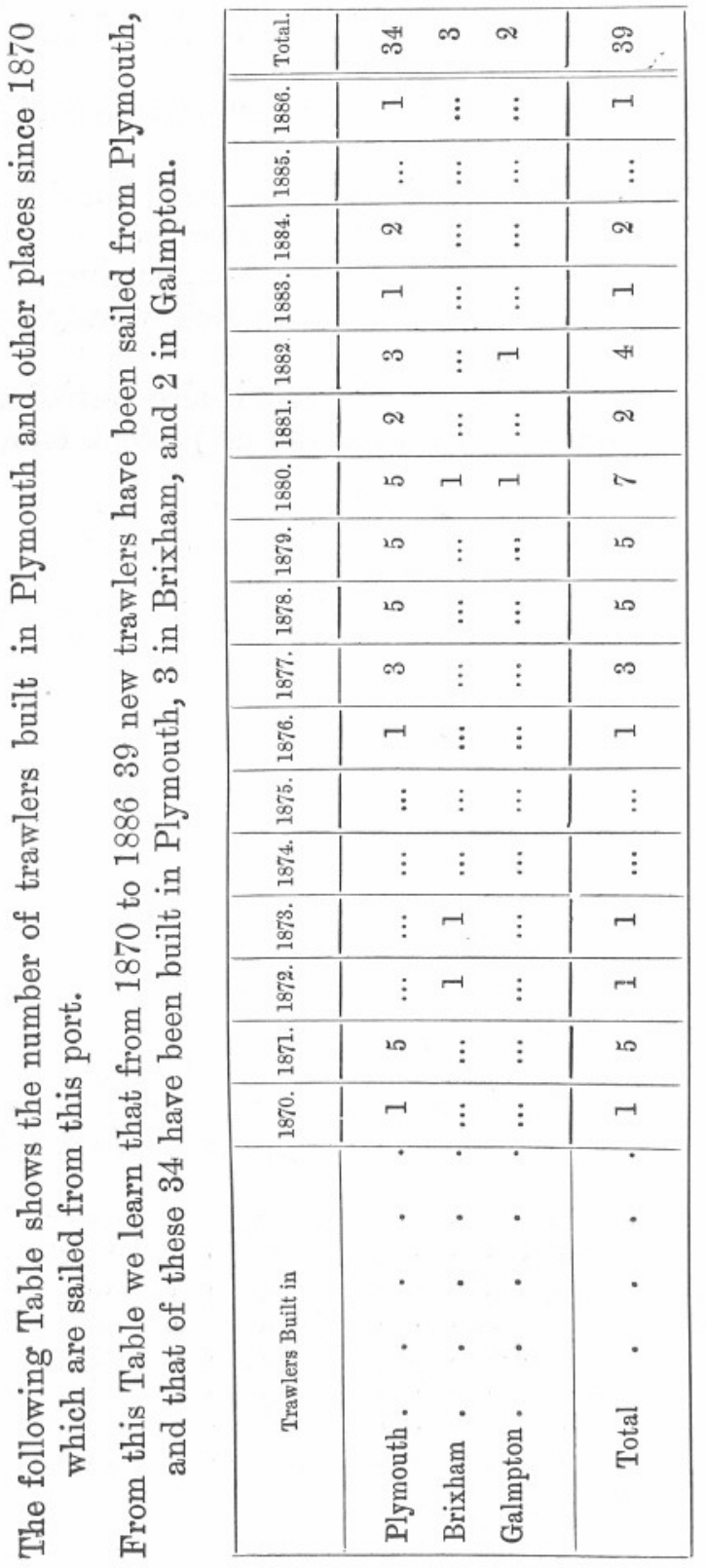

Drift Boats.-Drift boats are chiefly built in Penzance and St. Ives; a few are built in Porthleven, and Looe, and three boat builders in Plymouth also build them.

Hookers.-Hooking boats are built here in five yards and are also obtained from St. Ives.

\section{Sail Making.}

Sail making is carried on, I understand, on a sufficient scale to supply the wants of the port. The sails, which are supplied to the fishermen white, are tanned by them in order to make them last the longer.

Trawlers tan their sails with a solution of bark. Drifters, on the other hand, tan the sails of their boats with a solution of catechu, the same as they use for their nets.

\section{Rope Making and Fishing-line Making.}

These industries are carried on in Plymouth. In the case of fishing lines, however, the fishermen use, besides those made by local manufacturers, lines obtained from Ireland, Scotland, and London. The lines are sometimes "tanned" or "barked" by the fishermen themselves for preservative reasons.

\section{Net Breeding.}

Trawl Nets.-Trawlers breed their own nets, and the method used by them for preserving the net has already been mentioned on p. 49.*

Drift Nets.-Drifters do not obtain their nets in Plymouth ; particulars as to where the nets are made and how they are prepared by the fishermen here have already been given on p. 61 .

$$
\text { 5. Fish Curing. }
$$

Harring, Hake, Haddock.-Two or three small establishments are engaged in curing herring, hake, and haddock, but the business is only on a very small scale.

Pilchards.-A couple of establishments are concerned in the preservation of pilchards. Some few years ago pilchards were sent by rail and sea from Plymouth to be salted at St. Ives, Newlyn, and other Cornish ports. Now about half the pilchards landed here are cured on the spot.

* The cost of a trawl with spans and hawser is $£ 51$.

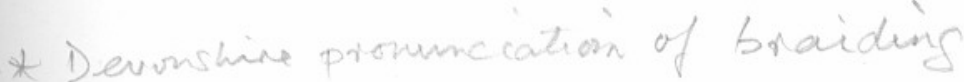


Pickling of Pilchards.-The new process of pickling the fish is carrried on here. Pickled fish, although perhaps not so much liked as salted fish, keep very much longer and are more profitable property. Salted pilchards must be disposed of soon after curing, while pickled fish can be stocked. Fish will keep in brine seven or eight months without deteriorating.

The pickling process is as follows:-The fish are thrown into vats and covered with brine; if judiciously renewed the brine will preserve the fish until required, when they are packed in barrels and shipped. Considerable pressure, by means of screws, is applied during packing, and the bottoms of the barrels being perforated, the oil contained in the fish is pressed out and escapes into vessels placed below to receive it. Fish so treated are called in the trade pickled or marinated pilchards.

Salting Pilchards.-Pilchards are salted in the following manner:- They are placed in layers, a layer of fish and a layer of salt, until the heap rises three to five feet high; they are left thus " in bulk" as it is called, for, say, thirty days, during which the brine and oil drain from them into pits; they are then sifted free of the remaining dry salt, washed, and packed in casks under pressure (No. 10). Such fish are known as "fumados" or "fair-maids."

Export Trade in Pilchards.-About 5000 hogsheads of pilchards are exported from Plymouth per annum. There are about 3800 fish in a hogshead, and therefore about 19,000,000 fish are cured here,-a very small quantity in comparison to the number passing through the Cornish curing establishments (No. 6).

Pilchard Oil.-The pilchard oil is used by rope and varnish makers and for preparing leather and mixing with paint.

\section{Fish-skin Curing.}

Two small fish-skin curing establishments are in existence here, one of these being on an exceedingly small scale.

Skate and Ray Skin.-The skin of skate and ray is cleaned by a chemical process and dried; in this condition it is sent away to merchants in other parts of the kingdom.
The Trade-How it is cleaned and to whom it is sent from here is known only to those concerned in the trade; while its ultimate destination and the purposes for which it is used is not known by those engaged in its preparation.

It is certainly used by brewers for "fining" beer, and that may be its only use.

\section{Fish-oil Manufacture.}

Fish Oil.-Besides pilchard oil, which has already (p. 84). been spoken of, oil is prepared from the livers of skate, ray, cod, and hake. The livers are boiled down and the oil collected.

Uses.-The oil is used for rope making and ship building, \&c., while the refuse solid matter, which at one time was used for soap making, is now unsaleable. There is only a small business carried on here in this manufacture.

\section{Ice Manufacture.}

Ice is manufactured in an establishment on the Fish Quay - the Ice Manufacturing Company-by the ammonia process. Ice is also obtained from Norway, and stored here by the Ice Manufacturing Company, who have accommodation for 550 tons, and by an ice merchant.

\section{III.-Methods of Ownership, Wage, Apprenticeship, Insurance, and Sale of Fish.}

This section may be divided into-

1. Payment of trawlers. 2. Payment of drifters. 3. Payment of hookers. 4. Systems of payment compared. 5. The insurance of trawlers. 6. The insurance of drifters and hookers. 7. Methods of selling and buying fish.

Owners.-Smacks are frequently owned by several individuals, who, as shareholders in the vessel, are paid in proportion to the amount of money invested, out of the receipts of the fishing. Not a few are, however, owned by individuals who are generally boat builders, fishermen, or others connected with the fishing trade.

"Working out" Trawlers.-Trawlers are at times built without orders, as a speculation by the builder, and facilities offered to young and energetic fishermen to enable them to 
become the owners of the vessel. The following method is usually adopted. A young man who is qualified, and is "second hand" on board some other boat, is offered the post of skipper on board the new vessel, and he undertakes to "work her out." He pays over year by year, out of his earnings, a proportion of the value of the vessel until a certain sum is in the hands of the builder, who then accepts a mortgage on the boat and the skipper becomes the owner and pays off the mortgage in instalments.

As will be seen in the following account, as skipper and owner he receives four and a half shares of the net proceeds of the catch.

Payments.-The men are paid on the share system, according to the value of the fish caught; the proportions of the shares varies, however, in the different kinds of fishing.

Insurance.-There are clubs for the insurance of trawlers, and of drifters and hookers managed entirely by the fishermen themselves in a very excellent fashion.

Fishermen.-The men who go fishing from this port are bonâ fide fishermen, they are not landsmen shipped during the fishing season and who work ashore during the rest of the year: such is the case with a great proportion of the crews of fishing boats on the Scotch coast during the herring. season and on the east coast of England, but here the men are brought up to the fishing business and understand all the details connected with the craft as only such men can.

Boys.-The few apprentices who are shipped on board these boats are well treated, the boys generally engaged are sons or relations of the skipper, owner, or one or other member of the crew of the smack in which he sails, and they are paid by a proportionate share of the value of the catch.

A complaint of ill-treatment made by a boy is, I understand, unknown here, and the good feeling and kindness existing was very favorably commented on by the committee appointed in 1883 to inquire into these matters (No. 21). The fishermen bear a character for thorough honesty and kind-heartedness, which I myself have every reason to believe is not exaggerated.

\section{Payment of Trawlers.}

The crews, a skipper, two men and one boy, find their own food while on board the smack.

Trawl Fish.-The net value of the catch of trawled fish is divided into seven shares. Of this the owner or owners of the boat have three; the skipper one and a half ; the second hand one; the third hand one; the boy a half.

Hook Fish.-In case fish is caught by hook and line on board the trawler, as may be the case if the boat is becalmed, the catch is divided into five shares. Of these the owner has one and a half; the skipper one; the second hand one; the third hand one; the boy a half.

Salvage.-In case of salvage, the sum received is divided into six shares. The owner has two and a half shares of the net amount of salvage paid; the skipper one; the second hand one; the third hand one; the boy a half.

Expenses.-All expenses connected with the boat and fishing gear, both renewals and repairs, are borne by the owner or owners of the vessel.

Stocker.-Besides these payments made to the crew there are certain perquisites the payment of which appears to be thoroughly understood, but which varies somewhat in different boats. The perquisites are locally known as "stocker." There are two kinds of stocker: (1) “men's stocker ;" (2) " boy's stocker."

(1) Men's Stocker.-Men's stocker consists of thickbacks (Solea variegata), queens (Pecten), male crabs ("he crabs"), lobsters, and possibly other produce.

(2) Boy's Stocker.-Boy's stocker consists of squid (Loligo) and female crabs (" she crabs").

The men's stocker is divided into three shares: and of these the skipper has one ; the second hand one; the third hand one.

The boy's stocker is divided into two shares; of which the third hand has one and the boy one.

The third hand has therefore a share of both men's and boy's stocker, but he may be paid about $2 s .6 d$. a week instead of receiving boy's stocker. 
"Pleasure Boy." - In case the trawler is a specially large vessel an extra hand may be employed, who is known as a "pleasure boy." He is paid wage by the owner and the crew, all joining in the payment; generally he is paid $2 s .6 d$. a week, and this sum is deducted from the net proceeds of the catch before it is divided into shares.

"Extra Boy."-On the other hand, in case the skipper is an old man, he may take an "extra boy" to help him in his work; in this case the boy is paid by the skipper alone.

Apprentices.-There are but few apprentices in Plymouth. In 1884, when the "Fishery Boats Act" came into force, there were five apprentices; since that date only ten others have been bound. The apprentice lives - with his master when on shore, and all food, \&c., is found for him ashore and afloat. He is generally bound to serve until twentyone years of age if he begins young, but if he is, say, eighteen years of age when he commences, a special arrangement is made as to the term he shall serve. An apprentice commences his service as “ boy," but he may become third hand, or even second hand, before his term of service is over. The following are the payments made to him while he remains apprentice :

Payment of Apprentice.-While serving as boy he receives from his master $6 d$. a week, and has besides half share of the " boy's stocker." His master takes the half share of the catch belonging to the "boy," and half share of the "boy's
stocker."

While serving as third hand he receives from his master $1 s$. a week, and has besides half share of boy's stocker, and one third share of men's stocker; he also has one quarter share of salvage in case there is any. His master takes the third hand's share of the catch, i.e. one share; also half a share of "boy's stocker," one sixth share of men's stocker, and three quarters share of salvage due to the third hand.

While serving as second hand he receives from his master $2 s$. a week, and has besides one third share of men's stocker, and one quarter share of salvage; his master taking the second hand's share of the catch, $i . e$. one share, two thirds share of the second hand's stocker, and three quarters share of his salvage money.

Earnings of Apprentice.-The apprentice is obliged to deposit his earnings with the officer of the Mercantile Marine, and is allowed from these earnings, during the first and second year of his service, $1 s$. a week " spending money," and during the remainder of his term $2 s$. a week. This is all the money he is allowed to have. Naturally the boy does not make a full return of his earnings ; if he did so, it is calculated that at the end of his term of apprenticeship he would have about $£ 25$ to $£ 50$ in the hands of the Mercantile Marine officer.

On completion of his term of apprenticeship to his master's satisfaction he receivès three suits of clothes, one pair of boots, one great coat, and $£ 11 s$.*

\section{Payment of Drifters.}

Plymouth Drift Fishermen.- The value of the catch is divided into eleven shares. Of these the owner has five and a quarter; skipper, one and a quarter; second hand, one; third hand, one; fourth hand, one; fifth hand, one; boy, half.

The owner finds the boat and all the gear, and makes good all repairs and losses.

On account of the greater comparative value of the nets employed in drift fishing, the owner has a considerably greater proportion of the gross amount of the catch than the owner of a trawler is allowed.

Cornish Drift Fishermen.-With the Plymouth system it is interesting to compare the system of payment adopted by Cornish drift fishermen. The latter is, in fact, a cooperative system, and is probably directly derived from the most primitive co-operative method.

The owner of a boat forms an "adventure" for each fishing season. For instance, in the mackerel season, the owner gets together a crew for his boat, who undertake to man his boat for the season.

* I am indebted for most of this information to Mr. W. H. G. Deacon, the Superintendent of the Mercantile Marine Office in Plymouth (No. 31). 
The "adventure" is divided into a number of shares, which vary in number according to the fishery prosecuted and the net-carrying power of the boat.

A mackerel boat of fifteen tons carries a skipper, six men, and a boy as crew.

In this case the adventure is divided into thirty-fourths, of which $\frac{*}{34}$ ths $=$ one share.

The owner who finds the boat and its gear and makes good damage, \&c., sustained by it has . . . 2 shares $=\frac{4}{34}$ ths.

The skipper who acts as ship's husband, and who makes a certain amount in that way has . . . 1 , $\frac{2}{34}$ ths.

The six men have each 1 share . . . . . 6 " $\frac{12}{34}$ ths.

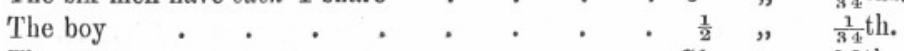

The nets . . . . . . . . $7 \frac{1}{2}$. $\frac{15}{34}$ ths.

$$
\overline{17} \text { shares }=\overline{\frac{34}{34}} \text { ths. }
$$

The nets are usually brought on board by the men engaged. One man may bring two nets, another one net, and so forth. The owners of the nets are paid in proportion to the number of nets they bring on board out of the sum ( $\left(\frac{15}{34} \mathrm{ths}\right)$ which is set apart for the nets. By this arrangement the undertaking has essentially the character of a co-operative society.

Cornwall is, I believe, the only county in England where this method is carried out by the fishermen.

The numbers of shares, as I have before said, in an adventure, vary according to the fishery and the net-carrying power of the boat, and this makes the agreements all the more complicated. There appears, nevertheless, to be an excellent understanding between the several parties who enter into these engagements every year, and a dispute is of very rare occurrence (No. 30).

\section{Payment of Hookers.}

Shares.-Among hookers the details are again different. The gross catch is divided into five and a half shares. The owner of the boat has one and a quarter shares ; the skipper, one and a quarter; second hand, one; third hand, one; and fourth hand, one.

Until recently the owner took one and a half shares and the skipper and three men one share each; now the owner divides his half-share with the skipper.

Men's Food.-The question of the men's food is treated differently on board hookers to what it is on trawlers. Any food which the crew may wish to have while fishing off the port they must find themselves; but if they go away to fish in other parts of the coast their food is considered as an expense attending the adventure, and its value is subtracted from the net proceeds of the trip before they are divided into shares. By this means the owner pays a proportion of the keep of the men while fishing away from home.

"Stocker."-Perquisites are claimed by hookers in most cases ; but the fish claimed for such "stocker" varies indefinitely, and the amount of it allowed for stocker differs according to the arrangements each owner may make with his crew. Some owners allow no stocker at all; others allow the skipper to sell a small "lot" of fish on his own account, or on account of the crew. As a general rule it may be said that if a few ling or pollack, two or three hake or conger only are caught during one day's fishing, this small lot may be disposed of by the skipper.

No particular fish is, as a rule, considered by hookers as their perquisite.

\section{Systems of Payment Compared.}

The method of paying fishermen entirely by poroportions of the proceeds of the catch of fish is, I am informed, universal in Cornwall and Devon, and, according to Professor Leone Levi (No. 16) is also in use in East Coast fishing ports.

Another system is, however, practised, at any rate in some of the latter ports (No. 23). According to this method, the owner pays a certain wage to the skipper and men, who receive besides, a share of the value of the catch.

In the Scotch herring fishery ports, the skipper is paid according to the catch, and the men paid wage. This was the case at Grimsby in 1877 in certain cases (No. 17 b), and in the North Sea Cod Fisheries a similar practice prevails now (No. 4). 
There are therefore three systems of payment in use among fishermen.

1. Payment by share. (A) When men are paid for work only (Plymouth trawlers). (в) When men are paid not only for work done but for fishing material supplied (Cornish drift fishers).

2. Payment by wage.

3. Payment partly by wage and partly by share.

As far as the greater number of men are concerned this latter method would appear most advantageous, viz. that they should have a small fixed income under all circumstances. They would thus be enabled to live when the trade is very unremunerative, but they would be stimulated to work hard in order to increase their income by sharing in the proceeds of the fishery as well.

Improvidence, Poverty.- There would appear to be a considerable number of fishermen in the port who do not recognise the importance of laying by money during good times, and in consequence of the irregular nature of the trade in which they are concerned and the enormous fluctuations in the price of fish, there are without doubt a large number of cases of poverty and distress amongst them during bad seasons.

In spite of this, however, the system of payment by share only, in use here, is considered by the better fishermen themselves, and by others who take an interest in the welfare of these men, to be by far the best system of payment, and calculated at any rate to make men independent, careful of money, hard workers, and watchful, shrewd fishermen.

\section{The Insurance of Trawlers.}

Mutual Insurance.-There is a mutual insurance club for trawling vessels, composed of the owners of vessels, and managed by a president and committee elected once a year from amongst themselves.

Rates.-The clubinsures for total loss only, the policy being limited to $£ 300$, for which there is an annual subscription of $\mathfrak{1}$.
For a 1st class trawler (a new boat and until 10 years old) the

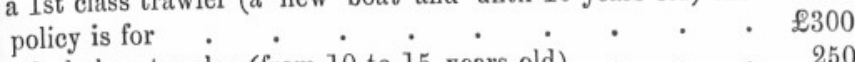
For a 2nd class trawler (from 10 to 15 years old) • • • 250 For a 3rd class trawler (from 15 to 20 years old) • • • 200

and there may be a further reduction for a boat more than twenty years old.

The exact times when the club determines to reduce its liability on any vessel, depends upon the committee of the club, who examine the vessels from time to time and class them in accordance with their age and condition.

Brixham.-At Brixham the trawlers can insure for total and for partial loss.

\section{The Insurance of Drifters and Hookers.}

Insurance.-The insurance of these boats is on a much smaller scale. The maximum amount of a policy is $\mathfrak{E} 60$, and the subscription $15 \mathrm{~s}$. a year. The club is managed in the same way as the trawlers' insurance club, the committee having power to determine the value of the policy any boat may take out. The maximum amount for which these boats may be insured is so small that several owners of the best boats will not insure their vessels.

The club, however, is in a flourishing condition.

\section{Methods of Selling and Buying Fish.}

Auction.-Fishermen place their catch in the hands of fish salesmen, who sell it, by auction, either to fish hawkers, local fishmongers, or fish buyers for London and other markets.

The auctions are of two kinds; either the lot is handed over to the highest bidder as in ordinary auction transactions; or, the lot to be sold is put up at a fancy price, the auctioneer reducing it until he reaches a figure which is accepted. This latter method is called "Dutch auction" and is very general on the east coast.

Commission.-The fish salesman charges 5 per cent. commission and guarantees the debt to the fishermen.

Discount.-All buyers of fish of a value of $20 \mathrm{~s}$. or more are allowed a discount of $2 \frac{1}{2}$ per cent. by the salesman, who thus makes $2 \frac{1}{2}$ per cent. on the amount he sells. 
Trawl Fish.-Trawl fish is sold as follows:- "Head" or "prime fish" is sold by the catch in lots, except hake, which is sold by the dozen. "Offal" or " seconds" is sold by the maund $*$, skate and ray by the "lot," which may be any number.

Drift Fish.-Drift fish is sold :-Pilchards, per 126; herrings, per 126 ; mackerel, per 120 .

Hook Fish.-Hook fish is sold :-Congers, per cwt.; ling, per dozen; skate and ray, per "lot" of any number; whiting, per dozen; pollack, per dozen; turbot, per fish.

List of Publications referred to.

No. 1. Ansell._ "On Trawling" ('Literature of International Fishery Exhibition,' 1883).

"2. Anson and Willett.-"Oyster Culture" ("Lit. of Int. Fish. Exhib.' 1883).

„, 3a. Bellamy._-'The Natural History of South Devon' (1839).

"3b. Bellamy.—'Guide to the Fish Market' (1862).

" 4. Bertram.- "The Unappreciated Fisher Folk"; ('Lit. of Int. Fish. Exhib.,' 1883).

„ 5. Brooks.—' General Guide to Sea Fishing.'

"6. Cornish._-"Mackerel and Pilchard Fisheries" ("Lit. of Int. Fish. Exhib.,' 1883).

, 7. Edinburgh, H.R.H. the Duke of.- "The Sea Fisheries and Fishing Population of the United Kingdom" ('Lit. of Int. Fish. Exhib.,' 1883.

8. Harding.- "Molluses, Mussels, Whelks, \&c., used for Food or Bait" ('Lit. of Int. Fish. Exhib.,' 1883).

9. Harding.- 'Specification No. 15,891." Apparatus for Storing, Keeping Alive, Fattening and Protecting from the Force of the Sea, Edible Molluses.

„10. Houghton.- "Natural History of Commercial Sea Fishes" ('Lit. of Int. Exhib.,' 1883).

,11. Holdsworth.- 'Sea Fisheries,' 1877.

", 12. Holdsworth._- "Apparatus for Fishing” ('Lit. of Int. Fish. Exhib.,' 1883).

„13. Hunt.- "Notes on Torbay" ("Transactions of the Devon Assoc.,' 1878).

„14. Inglis. - "Plymouth Sound-its Tidal Currents" ('Trans. of the Plymouth Instit.,' 1877).

* The weight of a maund of flatfish is, say, $70 \mathrm{lbs}$; of round fish, say,
$6 \mathrm{lbs}$.
No.15. Inglis. - "Harbour Accommodation in the West" ('Trans. of the Plymouth Instit.', 1885).

,16. Levi, Prof.-_"Economic Condition of Fishermen" ('Lit. of Int. Fish. Exhib.,' 1883).

„17. Lord.- 'Sea Fish and How to Catch them' (1862).

"17b. Lundie.- 'Statistics of Sea Fishery at Great Grimsby" (1877).

„18. 'Report of Select Committee on the British Channel Fisheries' (1833).

„19. 'Report of the Commissioners appointed to Inquire into the Sea Fisheries of the United Kingdom' (1866).

„20. 'Report on Crab and Lobster Fisheries of England and Wales, Scotland and Ireland' (1877).

,2 21. 'Report of the Committee appointed under a minute of the Board of Trade to Inquire into, \&c., Relations between Owners, Masters, and Crews of Fishing Vessels, \&c.' (1883).

„22. Scott.—"The Fisheries of Devonshire" ("Trans. of the Devon Assoc.,' 1864).

„23. "Systems of Wage of the North Sea Fishermen" (' Fish Trades Gazette,' No. 165, 1886).

„, 24. Wilcocks.—'The Sea Fisherman' (1884).

„25. Young.- 'Sea Fishing as a Sport' (1865).

„25b. 'Board of Trade Journal.'

I am, moreover, especially indebted to the following gentlemen for information contained in these notes:

No. 26. Captain Bate (Fisherman).

„27. Mr. R. Bunt (Fisherman).

„28. Mr. R. Cload (Fisherman).

„29. Mr. G. Coles (Fish Salesman).

" 30. Thos. Cornish, Esq. (Letters to W. F. Collier, Esq.).

" 31. W. H. G. Deacon, Esq. (Superintendent of the Mercantile Marine Office, Plymouth).

„32. Mr. Johns (Fisherman).

"33. Captain Short (Sutton Harbour Master).

„ 34. H. B. Watson, Esq. (Ship Builder).

To Mr. Coles my best thanks are due for a very large proportion of the facts included in Part I. 